\title{
Correction: Taking control: Is job crafting related to the intention to leave surgical training?
}

\section{Luis Carlos Dominguez, Laurents Stassen, Willem de Grave, Alvaro Sanabria, Edgar Alfonso, Diana Dolmans}

\section{Notice of republication}

An incorrect version of S1 File was published in error. This article was republished on July 31, 2018 to correct for this error. Please download this article again to view the correct version.

\section{Reference}

1. Dominguez LC, Stassen L, de Grave W, Sanabria A, Alfonso E, Dolmans D (2018) Taking control: Is job crafting related to the intention to leave surgical training? PLoS ONE 13(6): e0197276. https://doi. org/10.1371/journal.pone.0197276 PMID: 29856750

G openaccess

Citation: Dominguez LC, Stassen L, de Grave W, Sanabria A, Alfonso E, Dolmans D (2018)

Correction: Taking control: Is job crafting related to the intention to leave surgical training? PLOS ONE 13(8): e0202293. https://doi.org/10.1371/journal. pone.0202293

Published: August 8, 2018

Copyright: $\odot 2018$ Dominguez et al. This is an open access article distributed under the terms of the Creative Commons Attribution License, which permits unrestricted use, distribution, and reproduction in any medium, provided the original author and source are credited. 